\title{
The Cbronicle of Researcb and Scbolarly Events in Legal and Constitutional History at the Faculty of Law and Administration of the Jagiellonian University in 2018
}

Keywords: scholarly research, Legal and Constitutional History, Faculty of Law and Administration, Jagiellonian University

Słowa kluczowe: badania naukowe, historia państwa i prawa, Wydział Prawa i Administracji, Uniwersytet Jagielloński

In the year 2018, several research projects of the Chairs of the Faculty of Law and Administration of the Jagiellonian University which are concerned with legal and constitutional history were continued, and an important new one - project IURA - was launched. Apart from these, the faculty members and postgraduates, of the Chairs were engaged in cooperation with other academic centers, including several international conferences, and the preparation of a book devoted to the memory of Prof. Janusz Sondel (1937-2017). ${ }^{1}$ A very challenging but fruitful event was the $72^{\text {nd }}$ World Congress of SIHDA (Société Internationale Fernand de Visscher pour l'Histoire des Droits de l'Antiquité), organized by the Chair of Roman Law.

\section{Awards for the Professors of History of Polish Law}

In 2018, two professores emeriti of the Chair of Polish Legal History were acknowledged by public institutions in Cracow for their scholarly achievements.

1 Prawne aspekty podróży i turystyki - historia i wspótczesność. Prace poświęcone pamięci Profesora Janusza Sondla, Kraków 2018, 664 pp., Several articles written by present and former members of our Faculty, including K. Baran, A. Kociołek-Pęksa and W. Pęksa, M. Małecki, Ł. Marzec, M. Mikuła, M. Stus, P. Święcicka, W. Uruszczak, and K. Wyrwińska, were published in the book. 
On October 19, 2018, Professor Stanisław Grodziski was awarded the City of Cracow Award by the Mayor of the City, Prof. Jacek Majchrowski. The distinction was granted to him as an eminent scholar, whose contributions in the fields of editions of historical sources, history of legal culture, and various constitutional issues of the PolishLithuanian Commonwealth and the Polish lands after the partitions are (1772-1795) broadly valued and acknowledged.

On January 15, 2018, Professor Wacław Uruszczak, another professor emeritus and former head of the Chair of Polish Legal History, was awarded the Merentibus Medal. Prof. Uruszczak became thus the third professor of our Faculty - after S. Waltoś and S. Grodziski - to be honored with this high distinction by the Jagiellonian University. The event took place at a special session of the Senate of the Jagiellonian University in the Collegium Maius on January 15, 2018. It was headed by the Rector of the University, Prof. Wojciech Nowak, while Vice-Rector of the University, Prof. Dorota Malec delivered the solemn laudation for Prof. Uruszczak. Prof. Uruszczak himself also gave a speech, expressing his gratitude to his masters from days gone by, especially Prof. Adam Vetulani, as well as to his family and collaborators. ${ }^{2}$

\section{Chair of Polish Legal History}

Also in 2018 both emeriti of the Chair, mentioned above - Profs. Grodziski and Uruszczak - actively continued their research on various questions concerning constitutional and legal matters. Prof. Grodziski published the second, reviewed edition of his monograph on the Galician Seym, ${ }^{3}$ while Prof. Uruszczak was engaged in various activities related to the $550^{\text {th }}$ anniversary of Polish Parliamentarism (i.a., a conference on April 27, 2018 in Warsaw, and the publication of an anniversary album ${ }^{4}$ ). It is important to point out that the anniversary was being celebrated in 2018 thanks to Prof. Uruszczak's successful defense of the traditional date of the first assembly of the Polish parliament, including regular deputies of all the seymiks (dietines), in the year 1468, and not in 1493, as was asserted by other scholars. ${ }^{5}$

On September 24, 2018, the Council of the Faculty of Law and Administration of the Jagiellonian University adopted a resolution, by which Dr. Maciej Mikuła was granted the grade of habilitated doctor. In 2018, Dr. Hab. Mikuła and Dr. Hab. Grzegorz M.

2 Full texts of the laudation and Professor Uruszczak's speech may be found in the respective report: K. Krzysztofek, M. Mikuła, M. Ożóg, M. Strzała, Z. Zarzycki, Uroczystość wręczenia Medalu Merentibus Prof. dr. hab. Wacławowi Uruszczakowi, Kraków 15 stycznia 2018 r., „Studia z Prawa Wyznaniowego” 2018, no 21, s. 433-444.

3 S. Grodziski, Sejm Krajowy Galicyjski 1861-1914, t. 1-2, Kraków 2018, 732 pp., Studia Galicyjskie, vol. 5 (foreword: M. Małecki).

4 W. Uruszczak, M. Kornat, 550 lat parlamentaryzmu Rzeczypospolitej, Warszawa 2018, 352 pp.

5 Cf. W. Uruszczak, Najstarszy sejm walny koronny ,, dwuizbowy" w Piotrkowie w 1468 roku [in:] Narodziny Rzeczypospolitej: studia z dziejów średniowiecza i czasów wczesnonowożytnych, eds. W. Bukowski, T. Jurek, Kraków 2012, pp. 1033-1056.

Kronika wydarzeń naukowych - Cbronicle of scholarly events 
Kowalski continued their research on municipal law in Poland, ${ }^{6}$ and Dr. Jakob Maziarz conducted archival inquiries in the archives of L'viv, concerning the functioning of the courts during the Galician autonomy period and in the $2^{\text {nd }}$ Polish Republic, i.e. both before and after 1918. Chair faculty members, Dr. Hab. Izabela Lewandowska-Malec, Dr. Jakob Maziarz, and Dr. Władysław Pęksa, presented ten papers at conferences both domestic and abroad, including the $12^{\text {th }}$ European Social Science History Conference (Belfast, April $4^{\text {th }}-7^{\text {th }}$ ), and the conference Historical and Comparative Examination of Legal Professions in Jurisdiction and Administration in Szeged (co-organized by the NKE University in Budapest, the University of Szeged, and the Hungarian Academy of Sciences, in June of 2018). Several papers on legal-historical issues were also delivered at various conferences by scholars not employed directly by the Chair, but closely collaborating with it: Dr. Hab. Maciej Mikuła and Dr. Krzysztof Fokt; as well as by postgraduates of the Chair: Kacper Górski, Jakub Pokoj, and Damian Szczepaniak. I.a., M. Mikuła, K. Górski, and J. Pokoj delivered their papers at the $3^{\text {rd }}$ conference Wiosenne Spotkania Młodych (Spring Meetings of the Youth) in Łódź, April 16, 2018.

In July 2018, Dr. Władysław Pęksa lectured on The Creation of Legal Systems in Central and Eastern Europe in the $20^{\text {th }}$ Century during the International Summer School of Comparative Law, organized by the West Bohemian University in Plzeň. Among the guests who visited the Chair were Dr. Alexandra Letková from the Comenius University in Bratislava (Chair of Legal History and Comparative Legal Studies), and Mr. Zoltán Hegyesy from the NKE University in Budapest.

The Chair also continued its cooperation with the University of Szeged, which takes the form of regular seminars involving students and postgraduates (held in Szeged in 2018). It also supported the activities of law students from two student associations (the TBSP Section of Legal History, and Lex Publica), such as the international conference titled: $O$ nomen dulce libertatis! Prawne aspekty niepodlegtości i suwerenności na przestrzeni wieków (Kraków, $18^{\text {th }}-19^{\text {th }}$ May 2018), concerning the legal aspects of independence and sovereignty in the past.

In the section devoted to Polish legal history, it is important to mention the publication of the book concerning the legal situation and activities of non-Roman Catholic churches and religious associations in Kraków in the years $1945-1970^{7}$ by Dr. Hab. Katarzyna Krzysztofek from the Department of Church and Denominational Law.

6 I.a., the $2^{\text {nd }}$ edition of M. Mikuła's monograph on the Magdeburg Weichbild was published: Prawo miejskie magdeburskie (Ius municipale magdeburgense) w Polsce XIV - pocz. XVI w.: studium o ewolucji i adaptacji prawa, Kraków 2018, 383 pp.

7 K. Krzysztofek, Położenie prawne i działalność nierzymskokatolickich Kościołów i zwiazków wyznaniowych w Krakowie w latach 1945-1970, Kraków 2018, 453 ss. 


\section{Chair of the History of Administration and Administrational Ideas}

In 2018, Prof. Dorota Malec was intensely involved - both as Pro-Rector of the University and as a legal historian - in commemorating the centenary of Poland's independence, including the extent of the engagement of lawyers in the struggle for independence and unity of the state, and various issues concerning legislative and administrative practice which it had to cope with during the hundred turbulent years 1918-2018. I.a., during a scholarly session titled Uniwersytet u progu niepodległości (The University on the Threshold of Independence), held in Collegium Novum on May 8, 2018, she presented some remarks on the role that professors of the Jagiellonian University played in the legislative process in the $2^{\text {nd }}$ Polish Republic. She subsequently published her essay on law in Poland over the past 100 years. ${ }^{8}$ Prof. Malec also continued her research into the jurisprudence and history of Polish notaries and their professional self-governing bodies.

Dr. Hab. Paweł Cichoń continued his studies on the constitution, internal policy, and administration of the Free City of Cracow (1815-1846), and published several articles on those issues. Additionally - as co-author with Prof. Jerzy Malec - he published one more article presenting the history and activities of the Chair during the years 19792017. ${ }^{9}$ Dr. Marek Stus also continued his studies of certain topics that he had previously researched, i.a. the history of aerial law in Poland, and the history of Polish notaries. Dr. Michał Nowakowski conducted studies on the problems of law and administration in the People's Republic of Poland, especially the issue of administrative functions of economic arbitration in that period.

Collaborators of the Chair presented the results of their research through their publications (including several in English and French), as well as at various conferences, i.a. the $3^{\text {rd }}$ Annual Conference of the Central and Eastern European Network of Legal Scholars, in January of 2018 at the University of Latvia, Riga (Dr. Marek Stus); a conference in Jarosław on the history, and contemporary issues, of the Polish advocacy in June of 2018 (Dr. Hab. Paweł Cichoń); the $3^{\text {rd }}$ Wiosenne Spotkania Młodych (Spring Meetings of the Youth) conference in Łódź on April 16, 2018 (Dr. Marek Stus); and at the $27^{\text {th }}$ Polish Convention of Legal Historians and Historians of Legal and Political Doctrines in Lublin, 10 ${ }^{\text {th }}$ through 12 $2^{\text {th }}$ September, 2018 (Dr. Hab. Paweł Cichoń, Dr. Marek Stus, Dr. Michał Nowakowski).

8 English version: D. Malec, The Law in Poland during the Last 100 Years [in:] Poland: 100 Years, ed. M. Kleiber, Olszanica 2018, pp. 124-139.

9 P. Cichoń, J. Malec, Katedra Historii Administracji i Myśli Administracyjnej Uniwersytetu Jagiellońskiego w Krakowie (1979-2017), „Studia z Dziejów Państwa i Prawa Polskiego” 2018, vol. 20, pp. 289-301.

Kronika wydarzeń naukowych - Cbronicle of scholarly events 


\section{Chair of General Legal History}

In the Chair of General Legal History in 2018 most of the subjects which had previously been under investigation were studied further, but some new projects were launched, as well. Especially worth mentioning in this context is Prof. Andrzej Dziadzio's new project, which in May 2018 qualified for financial support from the National Research Centre (NCN) in the $14^{\text {th }}$ OPUS contest. Prof. Dziadzio's project, titled Prawo wtasności w orzecznictwie sadów Wolnego Miasta Krakowa: Z dziejów stosowania Kodeksu Napoleona (Code civil) (Property Law in the judicature of the Courts of the Free City of Cracow: From the History of Application of the Napoleonic Code Civil), has been focused on the complex historical, formal-dogmatic, and statistical analysis of relevant source materials, in order to obtain reliable insights into the practices of the Cracow judicature in civil cases, as well as valuable material for further comparative analyses.

Apart from his new project, Prof. Dziadzio was still working on various issues concerning the Austro-Hungarian Monarchy, i.a. the organization and tasks of the Galician Governorship, and the bill against usury in Galicia. Together with Prof. Stanisław Grodziski and Dr. Krzysztof Fokt, Dr. Hab. Marcin Kwiecień was elaborating volumes VI and VII of the Volumina Constitutionum (the project was supported by the Ministry of Research and Higher Education through the National Programme for the Development of Humanities [NPRH]). Dr. Jan Halberda continued his research on the questions of private law in the lands of Common Law (especially the institution of the promissory estoppel), and Dr. Piotr Michalik researched the evolution of British public law in the period of colonial expansion. Profs. Andrzej Dziadzio and Andrzej Bryk also expressed their opinions on various issues concerning the contemporary world, especially Poland, in their scholarly and popular press articles. In January 2018 postgraduate student of the Chair, Mgr. Paweł Dziwiński, spent a month at Vienna University in the framework of the direct exchange between the universities.

In 2018, the staff of the Chair and 8 postgraduate students preparing their theses under the supervision of Profs. Andrzej Dziadzio and Andrzej Bryk presented the results of their research at various conferences, domestic and abroad (only the professors of the Chair having presented 11 papers on seven conferences, not counting the postgraduates). I.a., Dr. Hab. Marian Małecki spoke about Polish-Turkish diplomatic relations throughout history at a conference in the University of Agri (Turkey) on October 24, 2018, and Prof. Andrzej Dziadzio addressed the hotly debated issues of the principle of Rule of Law in contemporary contexts and historical background at a conference in the Western Institute (Instytut Zachodni) in Poznań in April, 2018. Mgr. Paweł Dziwiński represented the Chair at several international meetings, i.a. at the $25^{\text {th }}$ International Medieval Congress (Leeds, $2^{\text {nd }}-5^{\text {th }}$ July, 2018), the $4^{\text {th }}$ International Conference Migrants and Refugees in the Law (Murcia, $12^{\text {th }}-14^{\text {th }}$ December, 2018), and the $3^{\text {rd }}$ Annual CEENELS Conference: Legal Traditions and Legal Identities in Central and Eastern Europe (Riga, $11^{\text {th }}-14^{\text {th }}$ January, 2018). Six representatives of the Chair took part in the convention of Polish legal historians in Lublin (September 2018), and four in the international conference titled Modernisierung des Staats- und Rechtssystems in der Habsburgermonarchie und ihre Auswirkung in Pecs (22 $2^{\text {nd }}-23^{\text {rd }}$ March, 2018). The latter is especially worth 
mentioning, as the collaboration of the Chair with its counterpart in Pecs, displayed in the biennial conference series, dates back to the year 2000. The results of research conducted by the pofessors of the Chair were presented in their publications, i.a. in issue 2 of volume 9 of the "Journal on European History of Law". It is also worth mentioning that Dr. Hab. Marian Małecki prepared the re-edition and extensive foreword to the second edition of Prof. Grodziski's monograph on the Galician Seym. ${ }^{10}$

\section{Chair of the History of Political and Legal Doctrines}

In the academic year 2018/19, Prof. Michał Jaskólski retired, remaining, however, in close contact with the Chair, now headed by Prof. Krystyna Chojnicka.

Dr. Hab. Iwona Barwicka-Tylek conducted her preliminary research in the framework of the NCN-supported "Miniatura" program, which would support a more extensive research project on the "Republic without towns": the republican thought and traditions of the First Polish Republic in the context of the contemporary rebirth of republicanism and the philosophy of the city. Dr. Hab. Barwicka-Tylek also took part in the project funded by the Płock Literary Society, titled Idee jako fundamenty porzadku społecznego, politycznego, i prawnego III Rzeczypospolitej (Ideas as Foundations of the Social, Political, and Legal Order of the $3^{\text {rd }}$ Republic of Poland), which resulted in her taking part in a conference and authoring an article in a volume on the same topic. She also presented the results of her research at several other conferences, i.a. in Rome (August/September, 2018) and Lucca (October, 2018).

The collaborators of the Chair prepared the $3^{\text {rd }}$ issue of the $11^{\text {th }}$ volume of the "Cracow Studies on Constitutional and Legal History". They also presented the results of their research on various occasions, i.a. through guest lectures (Dr. Agnieszka Czarnecka lectured on political myth in contemporary Poland at the School of Philosophy and Religious Studies of the Minzu University of China in Beijing, and Dr. Jacek Malczewski in Białystok: on medical law, euthanasia, and relief of pain and suffering in palliative care), and conference papers. The Chair was represented at the $27^{\text {th }}$ Polish Convention of Legal Historians and Historians of Legal and Political Doctrines in Lublin, and at the $17^{\text {th }}$ Convention of the Chairs of the History of Political and Legal Doctrines in Wrocław. Dr. Hab. Iwona Barwicka-Tylek and Dr. Anna Ceglarska also took part in the conference titled Mirror, Mirror: Perceptions, Deceptions, and Reflections in Time at the London Centre for Interdisciplinary Research, at the University of London (March 2018), Dr. Agnieszka Czarnecka presented her paper at the international Film-Philosophy Conference 2018 in Göteborg, and Dr. Anna Ceglarska in the $7^{\text {th }}$ International Scientific Conference on Idealized Design The "Democratic Man" and Security of Organisations in Kraków (January 2018).

The postgraduates preparing their doctoral theses in the Chair presented the results of their research through publications and papers presented at various scholarly meetings, i.a. during the Days of Law 2018 at the Masaryk University in Brno (Mgr. Piotr Eckhardt).

\footnotetext{
10 See above, footnote 3 .
} 
Also in 2018, one doctoral thesis, the dissertation of Mgr. Marcin Tomasiewicz, concerning pre-Augustinian historiosophic concepts, prepared under supervision of Prof. Krystyna Chojnicka, was finished and defended (diploma with distinction).

The Chair also collaborated actively with the Student Learned Society of Political and Legal Doctrines. Detailed information on the activities of the society may be found at its website: www.knhd.law.uj.edu.pl.

\section{Chair of Roman Law}

The most challenging and important undertaking of the Chair of Roman Law in 2018 was the organization of the $72^{\text {nd }}$ World Congress of SIHDA (Société Internationale Fernand de Visscher pour l'Histoire des Droits de l'Antiquité), being the most prestigious cyclical event in the world in the subdiscipline of Roman law studies. As the congress was held in autumn 2018, it also became one of the occasions to commemorate Poland's regaining of its independence a hundred years prior. The international meeting of scholars investigating ancient legal traditions was also contextualized into the tradition of the university, where Roman law was to be taught from its very beginning. Hence, the motto of the Jagiellonian University, rooted in Roman literary tradition - Plus ratio quam vis - was also accepted as the watchword of the congress. The President of the Republic of Poland, Dr. Andrzej Duda, bestowed honorary patronage over the congress. The proceedings opened with a solemn address by the Rector of the Jagiellonian University, Prof. Wojciech Nowak. Around 200 researchers from 28 countries took part in the Congress, which lasted from $11^{\text {th }}$ through $15^{\text {th }}$ September 2018, presenting 130 papers in French, English, Italian, Spanish, and German. Most of the proceedings were held in the Larisch Palace, belonging to our Faculty. ${ }^{11}$

On March 26, 2018, pursuant to the respective resolution of the Council of the Faculty of Law and Administration of the Jagiellonian University, Dr. Łukasz Marzec was promoted to the grade of habilitated doctor. It should also be mentioned, that in 2018 Dr. Grzegorz J. Blicharz was granted a prestigious scholarship for outstanding young scholars by the Ministry of Research and Higher Education of the Republic of Poland.

On April 14, 2018, during a scholarly conference held in Sucha Beskidzka, a group of Roman law scholars, including disciples of the late Prof. Janusz Sondel (Dr. Hab. Tomasz Palmirski, Dr. Paulina Święcicka, Dr. Karolina Wyrwińska, and Dr. Tomasz Szelagg) solemnly presented his widow with a volume of the commemorative book created in his honour. ${ }^{12}$ On that occasion, Dr. Hab. Tomasz Palmirski read a special letter from Prof. Dorota Malec, Vice-Rector of the Jagiellonian University, praising the scholarly achievements of the deceased.

11 Further details may be found in the published reports from the Congress: M. Pedone, Plus Ratio quam vis: la LXXII Sessione della SIHDA a Cracovia, „Index” 2018, no 46, pp. 855-860; K. Stloukalová, Plus ratio quam vis - At' rozum převáži nad silou, „Pravněhistorické Studie” 2018, no 49/2, pp. 230-233.

12 Semper fidelis: prace dedykowane pamięci Profesora Janusza Sondla, legendzie krakowskiego fakultetu prawniczego, eds. D. Malec, Ł. Marzec, T. Palmirski, Kraków 2017. 
In the autumn of 2018, the Head of the Chair, Prof. Franciszek Longchamps De Bérier, took part in two events in China. On $19^{\text {th }}-20^{\text {th }}$ October, 2018, he participated in the $10^{\text {th }}$ Anniversary of the China-EU School of Law (CESL), founded by the European Union in the China University of Political Science and Law (CUPL), as well as in the conference which was held on that occasion, titled The WTO at a Cross-Roads: Reshaping Its Normative Framework - Chinese and European Perspectives. With his lecture titled Institutional Reforms and Resilience of Law: the Experience of Private Law, Prof. Longchamps De Bérier was also among the scholars from 11 countries, who presented their papers during the annual CASS Forum: International Symposium on Rule of Law, which was held in on November $16^{\text {th }}-17^{\text {th }}, 2018$ in the Chinese Academy of Social Sciences in Beijing. Prof. Longchamps De Bérier also appeared on an expert panel during a student conference titled 100-lecie odzyskania niepodległości - bilans $i$ perspektywy (100 th Anniversary of Independence - Balance and Perspectives), and spoke about Roman law as part of the Polish legal tradition.

In 2018, the team headed by Dr. Hab. Tomasz Palmirski (including himself, Dr. Krzysztof Hilman, and former collaborator of the Chair, Dr. Hab. Jarosław Reszczyński, as author of the Preface) published the text of the Institutions of Emperor Justinian and its translation into Polish. ${ }^{13}$

On July 1-8, 2018, students, PhD candidates, and professors of the Chair took part in the international workshops titled Roman Law and the Modern World in and around Rome and Naples, including scholarly seminars, and the visiting of ancient monuments, libraries, and museums. As usual, the Chair was also engaged in organizing contests for students, concerning their knowledge of Roman law and its role in the contemporary world.

\section{Laboratory of Source Editions}

In 2018, work on two major projects was continued in the Laboratory of Source Editions, namely the Fontes Iuris Lusatiae Superioris Vetustissimi (headed by Dr. Krzysztof Fokt), and Volumina Constitutionum (headed by Dr. Hab. Marcin Kwiecień). The most important results in the former field were the publication of the second part of the critical edition of the oldest book of records of the town of Görlitz, ${ }^{14}$ and the organization of the second project seminar in Zgorzelec. ${ }^{15}$ In the "Volumina Constitutionum" project, the elaboration of volumes 6 and 7 was continued. Both abovementioned projects were aided by the Polish Ministry of Research and Higher Education through the NPRH program (National Programme for the Development of Humanities).

\footnotetext{
13 Institutiones Iustiniani: Instytucje Justyniańskie: Tekst i przekład, Kraków 2018.

14 Liber Vetustissimus Gorlicensis. Das älteste Görlitzer Stadtbuch / Najstarsza księga miejska zgorzelecka 1305-1416 (1423), Teil/Część II (1343-1389), eds. K. Fokt, C. Speer, M. Mikuła, in cooperation with R. Koszellni, Kraków 2018.

15 Two articles resulting from the seminar and the seminar report may be found in the $4^{\text {th }}$ issue of the previous volume of the „Cracow Studies on Constitutional and Legal History”.
} 
Another project, headed by Dr. Hab. Maciej Mikuła, with a goal of creating a digitized database of sources of law from the past was also launched in the Laboratory. It is, namely, the IURA project, which is going to become a nodal point where late normative sources, legal literature, and acts illustrating the practice of jurisdiction and administration would merge into one database. This will allow for quicker and deeper research in the field of constitutional and legal history in the future. The project started thanks to support provided by the Faculty, represented by the Dean and Vice-Dean, Profs. Jerzy Pisuliński and Bartosz Brożek. Several researchers not only from the Jagiellonian University, but also from other research centers in Poland, declared their willingness to join it. The url of the project, technically supported by the Poznań Supercomputing and Networking Centre, is https://iura.uj.edu.pl/.

This chronicle was prepared by Dr. Krzysztof Fokt; much of the information was obtained through the kind collaboration of Dr. Hab. Iwona Barwicka-Tylek, Dr. Anna Ceglarska, Mgr. Pawet Dziwiński, Dr. Hab. Łukasz Marzec, Dr. Piotr Michalik, Dr. Władysław Pęksa, and Dr. Marek Stus. 